\title{
Wycieczki inferencyjne thumacza z wyobraźnią w tle
}

Wyobraźnia jest formą świadomości nieposiadającą swego przedmiotu, jak również medium łączącym konkretną nieobrazową wiedzę z przedstawieniami. Jest świadomością twórczą, która jak chciał Gaston Bachelard - oznacza w poezji (literaturze) wrażliwość na semantyczne niuanse słowa, mające zdolność tworzenia obrazów ${ }^{\mathrm{I}}$. Obrazy te pozostają w bezpośrednim związku z rzeczywistością nie przez denotację, lecz przez konotację, dzięki czemu potencjalność jest ich zasadniczą właściwością. Wyobraźnia objawia się osobowo po stronie aparatu nadawczego utworu literackiego (autora jako podmiotu postrzegającego i podmiotu sprawczego) i odbiorczego (czytelnika jako podmiotu postrzegającego) oraz tekstowo, manifestując się w ukształtowaniu semantycznym i kompozycyjnym. Literaturę jako wytwór wyobraźni charakteryzuje intencyjność (na poziomie aktu mowy) i intencjonalność (na poziomie bytowym). Utwór wymaga współpracy z wyobraźnią odbiorcy, ufundowaną - podobnie jak wyobraźnia nadawcza - na zdolnościach mentalnych umysłu i bodźcach zewnętrznych, doświadczanych zmysłowo i umysłowo. Czytelnik aktualizuje potencjał semantyczno-obrazowy tekstu stosownie do własnej wiedzy oraz istniejących w określonym czasie i określonej przestrzeni paradygmatów myślowych i postrzeżeniowych (np. wprowadzenie perspektywy w malarstwie, elektroniczne środki informacji) w zakresie nauki, kultury i sztuki ${ }^{2}$.

Aktywność tłumacza plasuje się po stronie odbiorcy i po stronie drugiego nadawcy. Tłumacz aktualizuje ścieżki wyobraźni

${ }^{\text {I }}$ Por. G. Bachelard, Wyobraźnia i materia, thum. A. Tatarkiewicz, w: idem, Wyobraźnia poetycka, tłum. H. Chudak, A. Tatarkiewicz, wybór. H. Chudak, przedmowa J. Błoński, Warszawa 1975, s. 113-119.

${ }^{2}$ Por. T.S. Kuhn, Struktura rewolucji naukowych, thum. H. Ostromęcka, posłowie tłum. J. Nowotniak, Warszawa 2001. 
oryginału przez pryzmat własnej wyobraźni, wiedzy o kulturze wyjściowej i kulturze docelowej wraz z dominującymi w nich paradygmatami myślowymi i postrzeżeniowymi tak, by dokonywany przez niego transfer za pomocą innego języka pozwalał odbiorcy docelowemu na podobny kontakt $\mathrm{z}$ tekstem jak oryginał. $\mathrm{W}$ procesie transferu sensu za pomocą innego kodu językowego zmuszony jest dokonywać zmian w zakresie niektórych kategorii gramatycznych, a nawet znaczeń pojedynczych słów, po to, by zachować potencjalność wyobrażeniową oryginału jako elementu składowego sensu. Łącząc nieobrazową wiedzę odbiorcy docelowego (wiedzę kontekstową odnośnie do oryginału i własnej kultury) z przedstawieniami (istniejącymi w kulturze przyjmującej i proponowanymi przez thumacza), napotyka tym samym trudności wynikające z różnic między dwoma paradygmatami, oryginału i przekładu. Tłumacz zachowuje w ten sposób szacunek dla tekstu i kultury wyjściowej, a jego przekład może stanowić wzbogacenie kultury docelowej, ponieważ obcy paradygmat wprowadzony w kod drugiego języka prowadzi do weryfikacji znanych doznań i myśli, a ponadto wskazuje nowe obszary poznawcze. Wraz ze zmianą paradygmatu poznawczego - zastosowania odmiennych narzędzi oglądu rzeczywistości - zmienia się świat, czyli także świat własnej kultury i obraz siebie samego. I choć nie przekłada się paradygmatów, jak pisze Edward Balcerzan', paradygmaty określają przesłanki rozumienia rzeczy, zjawisk, również tekstów. Zatem mimo że język nie jest tekstem, lecz systemem, to tekst stanowi element aktu komunikacji kulturowej, a ta opiera się na istniejących paradygmatach (także paradygmatach języka), będących przesłankami jego rozumienia. Tekst wynika z interakcyjności komunikacyjnej w granicach obowiązujących paradygmatów. Jednym $\mathrm{z}$ nich jest system językowy. Ze względu na funkcję komunikacyjno-poznawczą przekładu, zmianę porządku paradygmatycznego rozumienia oryginału, w tym języka, ekwiwalencja językowa ma charakter stopniowalny, zależny w znacznej mierze od możliwości wyobrażeniowych thumacza, zdolnego „wyeksportować” czytelnika w nieznaną mu kulturę i wywołać refleksję nad jego własną kulturą̧. Tekst bowiem zawsze istnieje w jakimś kontekście i zawiera uznakowiony kontekst ${ }^{5}$. Istniejąc w kontekście,

3 Por. E. Balcerzan, Stowo wstepne (Przektad calkowity, czyli opotędze biperboli), w: P. Ricoeur, P. Torop, O thumaczeniu, thum. T. Swoboda, S. Ulaszek, wstęp E. Balcerzan, Gdańsk 2008, s. 27-28.

4 Por. ibidem, s. 24 - uwagi Edwarda Balcerzana na temat aktywnego i potencjalnego porządku paradygmatycznego uwzględniają reguły i teorie wypełniające paradygmaty.

5 Por. m.in.: M.R. Mayenowa, Poetyka teoretyczna w Polsce. Zagadnieniajezyka, Wrocław 1974, s. 262-317; T. Dobrzyńska, Tekst. Próba syntezy, Warszawa 
wymaga udziału czynnika pozatekstowego, ponieważ zakłada odczytanie znaczenia i sensu przez czytelnika, zaktywizowania jego wyobraźni. Równocześnie stanowi jednostkową konceptualizację postrzeganej rzeczywistości za pomocą konwencji i zmiennych w czasie sposobów uznakowienia. Zatem zewnętrzne (kontekst) jest elementem konstytutywnym tego, co wewnętrzne (tekstu) ${ }^{6}$.

Teksty są jednakże uznakowioną formą rzeczywistości, która konceptualizuje różne jej dziedziny z perspektywy podmiotu postrzegającego i podmiotu sprawczego oraz podmiotu literackiego. Przynależąc do określonej kultury, są formami jej zinterioryzowania $\mathrm{w}$ doświadczeniu zmysłowym i umysłowym. Tłumacza interesuje efekt tekstowy tego zinterioryzowania wtedy, kiedy wysyła swego czytelnika do świata innej kultury. Dysponuje większą od niego wiedzą o autorze i kulturze wyjściowej oraz przewiduje jego oczekiwania. W konsekwencji czytelnik przekładu obcuje z przedstawieniem (oryginału) bez podmiotu przedstawiającego (ten jest ukryty w transformacjach dokonanych przez tłumacza, który w pewnym stopniu staje się „drugim autorem" 7 ) oraz z reprezentacją (oryginał) bez rzeczywistości reprezentowanej.

Praca wyobraźni odbiorcy docelowego wymaga tych samych bodźców tekstowych, jakie zawiera oryginał. Zważywszy jednak na fakt, że ma on do czynienia z przedstawieniem oryginału i powtórną konceptualizacją rzeczywistości, tłumacz jest zmuszony stworzyć mu za pomocą własnej wyobraźni iluzję przebywania z oryginałem. I tak się dzieje, o czym może świadczyć częste zapominanie przez czytelnika nazwiska tłumacza, pomimo że to on wprowadza odbiorcę w nieznany świat, uczy dostrzegać to, co niekoniecznie stanowi jego doświadczenie wizualne i pojęciowe. Obcowanie z wytworem innego paradygmatu myślowego, doznaniowego i uczuciowego zmienia nie tylko interpretację rzeczy znanych, lecz także zrozumienie spraw podstawowych, pozwalających wzbudzać nowe sensy postrzeganej rzeczywistości. Nie przeszkadza w tym zmiana przesłanek rozumienia tekstu wynikająca $\mathrm{z}$ innego porządku paradygmatycznego, pod warunkiem że tłumacz odczyta charakter i cel wycieczek inferencyjnych obecnych w oryginale, które aktywizują wyobraźnię czytelnika, czyniąc lekturę interesującą. Wymaga to naśladowania mechani-

1993; A. Duszak, Tekst, dyskurs, komunikacja międzykulturowa, Warszawa 1998; U. Eco, Lector in fabula, tłum. P. Salwa, Warszawa 1994.

${ }^{6}$ Por. J. Derrida, O gramatologii, thum. B. Banasiak, Warszawa 1999, a także: U. Eco, op.cit. s. 20.

7 Zob. A Legeżyńska, Thumacz i jego kompetencje autorskie, Warszawa 1999, 
zmu generowania wyobraźni oryginału, ponieważ może zaistnieć konieczność pewnych przesunięć w zakresie jego wypełnienia ze względu na zmianę przesłanek rozumienia tekstu w kulturze docelowej przekładu. Przesunięcia te mogą wynikać zarówno ze zmiany systemu językowego, jak też z odmiennych systemów wartości, posiadanej wiedzy, wyobraźni jednostkowej i zbiorowej, światopoglądu, konwencji artystycznych, systemów kształcenia, rządzenia i handlu oraz stylu komunikacji kulturowej.

Tłumacz KrzesetEugène’a Ionesco, Jan Kosiński, chcąc zachować organizującą rolę rytmu (zawarta jest w nim również krytyka stereotypu), dokonał wielu zmian na poziomie poszczególnych znaczeń, najczęściej tam, gdzie tekst eksponuje nieużyteczność słowa jako środka komunikacji. Są to drobne modyfikacje. W oryginale czytamy:

La Vielle: Est-ce une fleure Monsieur? ou un berceau? ou poirier? ou un corbeau? ${ }^{8}$

'Czy to kwiat, proszę pana? czy kołyska? drzewo gruszy? czy kruk?',

w tłumaczeniu:

Stara: bierze prezent: Czy to kwiat, proszę pana? Czy kołyska? Drzewo owocowe, walizka9.

Innym razem zmiana znaczeń jest zupełna. W oryginale:

La Vielle [...]: Pour préparer de crêpes de Chine? Un oeuf de boeuf, heure de beurre, une sucre gastrique $[. . .]^{\text {To }}$.

une]

'Przepis na chińskie naleśniki? Jaja wołu, godzina masła, cukier gastryczny',

w przekładzie:

Stara: Przepis na suma po bajońsku, osełka masełka i maku do smaku $[\ldots]^{\text {II }}$.

${ }^{8}$ E. Ionesco, Les chaises. Farce tragique. Suivi de L'impromptu de l' Alma, Paris 1984, s. 41. s. 186.

9 E. Ionesco, Krzesta, w: idem, Teatr, tłum. J. Kosiński, t. 1, Warszawa 1967,

то E. Ionesco, Les chaises, s. 45.

${ }^{\text {II }}$ E. Ionesco, Krzesta, s. 188. 
W obu przypadkach tłumacz zmienił wypełnienie mechanizmu generującego sens i wyobrażenie o postaci dotkniętej demencją starczą, uzyskując taki sam efekt jak w oryginale. Skierował konkretyzację czytelniczą w stronę bezsensu komunikacji językowej, która jest jedna z form wypełniania pustki, meubler le vide, za pomocą takiej samej funkcjonalnie „wycieczki inferencyjnej”. Znaczenie ulega więc w Krzesłach zużyciu, a język - jako continuum - rozbiciu. Afatyczne wypowiedzi bohatera odsłaniają mechanizm scalania i ponownego rozpadania się wyrazu na poziomie fonetyczno-fonologicznym, wskutek czego znaczenie pojawia się i ginie. O ile wskazane przykłady świadczą o respektowaniu przez thumacza inferencyjności oryginału, to zawodzi on czytelnika w innym momencie, kiedy nie wiadomo dlaczego odchodzi od przyjętego w oryginale mechanizmu gry sensu i bezsensu ku próbie szukania sensu. Mam na myśli fragment, w którym Stary, powtarzając na prośbę Starej tę samą opowieść, próbuje wypełnić codzienną pustkę. Gdy okazuje się, że ma on kłopoty z wysłowieniem się, ponieważ nie może sobie przypomnieć odpowiednich słów, ona przypomina początek: „,...] alors on a ri..." ${ }^{{ }_{2} 2}$ (więc śmialiśmy się...), po czym Stary kontynuuje. Thumacz przekłada początek następująco: „[...] wtedy jech...” ${ }^{\text {I3 }}$, ponieważ słowem docelowym jest czasownik arriver (jechać). W tekście Ionesco powstaje swoisty ciąg fonologiczny: ri... (od rire - śmiać się) $\rightarrow$ arri... (od arriver - jechać $) \rightarrow$ on a ri $(3 \mathrm{sg}$. passé composéod arriver $) \rightarrow$ de riz $($ ryż $) \rightarrow$ on a ri $\rightarrow$ de riz $\rightarrow$ on a ri $\rightarrow$ arriva ( $3 \mathrm{sg}$. future simple od arriver) $\rightarrow$ on a ri..., by w pewnym momencie przekształcić się w głośny, zaraźliwy śmiech obojga Starych. Tłumacz, rozpoczynając od ,jech...”, niszczy efekt narastania błazenady, bezsensownej zabawy, demencji starczej, lecz również stanu otępienia ograniczającego możliwości wzajemnego porozumiewania się. Zabrakło zatem ujawnienia w continuum fonologicznym języka przekładu mechanizmu rozpadu i scalania, choć język polski częściowo taką możliwość daje, np.: cha... $\rightarrow$ jecha... Można przypuszczać, że zawiodła w tym miejscu wyobraźnia językowa tłumacza lub że wybrał rozwiązanie, jakie stanowi dowód potwierdzający tezę skrajnych relatywistów językowych: o niemożności przekazania w drugim języku tego samego, co komunikuje język wyjściowy ${ }^{\mathrm{I}} 4$.

I2 E. Ionesco, Les chaises, s. 17.

${ }^{13}$ E. Ionesco, Krzesta, s. 169.

${ }^{1} 4 \mathrm{Na}$ temat postawy relatywistycznej i uniwersalistycznej w językoznawstwie, szczególnie na temat językowej kategoryzacji świata oraz relacji między kulturą, historią, doświadczeniem zmysłowym, emocjami a językową konceptualizacją, pisze między innymi Anna Wierzbicka (zob. eadem, Język - umyst kultura. Wybór prac, red. J. Bartmiński, Warszawa 1999). 
Naśladowanie w przekładzie wycieczek inferencyjnych ${ }^{15}$ obecnych w oryginale to dla odbiorcy docelowego okazja do uruchomienia jego własnej wyobraźni; lektura staje się interesująca przez włączenie go w przestrzeń tekstu. Tłumacz stwarza w ten sposób warunki do przewidywania dalszych wydarzeń, nastrojów, stanowisk, czyli dostarcza bodźców do pracy wyobraźni opartej na wiedzy nieobrazowej i znanych lub wyobrażanych przedstawieniach. Przesłanki mogą być prawdziwe albo fałszywe. Te fałszywe ujawniają anomalie $\mathrm{w}$ zdeterminowanym naukowo i kulturowo powstawaniu sądów, w kojarzeniu faktów czy w ich przeżywaniu. Naśladowanie dokonane za pomocą innego języka pozwala na konfrontację z tym, co pozornie podobne, lecz okazuje się odmienne. Zaskoczenie powstałe w systemie oczekiwań odbiorcy wzbogaca go, podobnie jak kulturę przyjmującą, pod warunkiem że jest ono zrozumiałe. Tłumacz, odkrywając obcego w sobie i we własnej kulturze oraz siebie i swoją kulturę w obcym ${ }^{\mathrm{I} 6}$, uruchamia - już na etapie dewerbalizacji - dwuwartościową wyobraźnię, a na etapie reekspresji znajduje dla niej ekwiwalent semantyczno-stylistyczny, który stanowi możliwy inwariant tekstu wyjściowego. W tym celu praca jego wyobraźni koncentruje się na przekazaniu sensu utworu i konkretnej, nieobrazowej wiedzy o elementach językowych wyrażenia tego sensu, czyli znaczeniach denotowanych i konotowanych na różnych poziomach języka w perspektywie sensu całości i modelu świata w niej przedstawionego. Od niego zależy, czy czytelnik przekładu w przeżyciu estetycznym dozna przyjemności obcowania $\mathrm{z}$ tekstem, $\mathrm{z}$ przedstawieniem (najczęściej bez znajomości rzeczywistości reprezentowanej), czy odkryje w niej siebie i układy wyobraźni znane z własnej kultury, czy dozna przyjemności zaskoczenia z odkrycia obcego $\mathrm{w}$ sobie. Odkrycie obcego w sobie polega na zobaczeniu siebie i swojej kultury $\mathrm{w}$ paradygmacie innej kultury i innej rzeczywistości. Zmiana paradygmatu zmienia obraz świata lub go uzupełnia o inną perspektywę (jak świadomość wielowartościowa), uzupełnia sposób postrzegania, ponieważ: „To, co człowiek widzi, zależy od tego, na co patrzy, co nauczył się dostrzegać w swym doświadczeniu wizualnym i pojęciowym" - jak pisze Thomas $S$. Kuhn ${ }^{17}$. Wyobraźnia tłumacza powinna więc mieć charakter dwukierunkowy, by w materii drugiego języka wyrazić niepowtarzalność oryginału, wpisując jego paradygmat językowy w reprezentację nieobecnej dla odbiorcy sekundarnego rzeczywistości reprezentowanej.

${ }^{15}$ Zob. U. Eco, op.cit.

I6 Teza A. Bermana, a także P. Ricoeura - por. P. Ricoeur, Radość i udręki thumaczenia, w: P. Ricoeur, P. Torop, op.cit., s. 33-38.

${ }_{77}$ T.S. Kuhn, op.cit., s. 201. 
Dlatego thumacz nie tylko uruchamia swą wyobraźnię semantyczną z zakresu znaczeń języka rodzimego w relacji do wyobraźni semantycznej w języku wyjściowym, lecz podejmuje grę $\mathrm{z}$ odbiorcą docelowym na poziomie możliwości odczytania przez niego topicu $\mathrm{z}$ wielu sygnałów i amalgamatów semantycznych, ustalając właściwy poziom znaczenia czy izotopię. Izotopia służy ustaleniu poziomu interpretacyjnego. Jest to „zbiór redundantnych kategorii semantycznych umożliwiających jednolite odczytanie danej historii" ${ }^{8}$ o charakterze semantycznym, fonetycznym, prozodycznym, stylistycznym, retorycznym, presupozycyjnym, syntaktycznym i narracyjnym ${ }^{19}$. Odczytawszy topic i izotopie, thumacz rekonstruuje mechanizm ich powstawania w innym materiale językowym tak, by nie naruszyć sensu oryginału i jego struktury, dbając przy tym o doznania lekturowe odbiorcy sekundarnego, porównywalne z doznaniami czytelnika prymarnego. Należy podkreślić, że takie wycieczki inferencyjne są mocno ograniczone. Nie dotyczą konceptu, narracji, bohatera, akcji itp. Odnoszą się wyłącznie do nacechowanej w oryginale semantyki na poziomie fonemów, leksemów, wykorzystania prozodii języka (np. do celów rytmizacji), morfologii, syntaktyki, językowych możliwości uzyskania presupozycji, do poziomu ekwiwalencji stylistycznej. Tłumacz ukierunkowuje więc wycieczki inferencyjne czytelnika za pomocą dysjunkcji (opozycji) prawdopodobieństwa na wymienionych poziomach. Wycieczki inferencyjne oznaczają dopuszczane $\mathrm{w}$ tekście przewidywania odbiorcy, który na podstawie sygnałów wewnątrztekstowych (w polu działania tłumacza znajdują się sygnały często odmienne w zakresie drugiego słownika i gramatyki) wychodzi poza tekst w kierunku znanego doświadczenia, uruchamiając znane scenariusze. Zaskoczenie pozwala odkryć inne możliwości i rozwiązania przez wskazanie innego punktu widzenia. Tłumacz powinien wykorzystać zaskoczenie, to obecne w oryginale, a także to, które wynika $\mathrm{z}$ innego sposobu konceptualizacji i kategoryzacji w języku sekundarnym, by uzyskać sens i funkcjonalność oryginału. Często dochodzi wówczas do przekroczenia normy językowej w przekładzie, na przykład na poziomie norm słowotwórczych (neologizmy) lub praktyki składniowej czy spójności tekstowej (składnia jukstapozycyjna w językach unikających jej czy dyslokacje w językach tradycyjnie pozycyjnych lub o wyraźnie określonym porządku składniowym). Dokonując ich, tłumacz kieruje się zwykle porządkiem oryginału i sensotwórczą rolą

\footnotetext{
I8 A.J. Greimas, Du sens, Paris 1970, s. 188. Cyt. za: U. Eco, op.cit., s. 134.

I9 Por. U. Eco, op.cit., s. 125-178.
} 
określonych rozwiązań. W ten sposób Adam Ważyk znakomicie przetłumaczył Strefę Guillaume'a A pollinaire’a, zapoczątkowując kubizm w poezji polskiej, natomiast tłumacze opowiadań Sławomira Mrożka na język słoweński pozbawili je w większości przypadków gry ironią i wieloznacznością (ponieważ nadali tekstom spójność składniową, jednoznacznie je interpretując) oraz odebrali im modalność naśladującą tryb subjonctif w języku francuskim. Przekroczenia normy własnego języka nie mogą jednak naruszyć granicy zrozumiałości i akceptabilności u czytelnika, czym można uzasadnić niektóre zabiegi słoweńskich tłumaczy dokonywane na tekstach Mrożka.

Respektowanie wycieczek inferencyjnych oryginału stanowi konieczność zachowania sensu niezależnie od tego, czy jest to poziom fonetyczno-fonologiczny (jak w Krzestach Ionesco), czy poziom łączliwości obrazowo-semantycznej i składniowej jako skutku nowego postrzegania świata (jak w przekładzie Strefy Apollinaire'a), czy poziom składni (jak w thumaczeniu opowiadań Mrożka na język słoweński), czy wreszcie styl komunikacji kulturowej (jak w słoweńskim przekładzie Trans-Atlantyku Gombrowicza).

Adam Ważyk, poeta, tłumacz Strefy, zafascynowany niekonwencjonalnym widzeniem świata w poemacie Apollinaire'a, już w pierwszej drukowanej wersji przekładu ${ }^{20}$ pozwala prowadzić się oryginałowi. Przestrzega równoczesności planu percepcji zmysłowej miasta, refleksji nad nim i rozrachunku z własnym życiem. Nie wprowadza nadmiernej spójności wewnątrz tekstu. W konstrukcjach składni jukstapozycyjnej zostaje bowiem wyeksponowany wszechogarniający ruch; w nim zderzają się przeciwieństwa rzeczy, zjawisk, ludzi i wydarzeń. Czytelnik przekładu, podobnie jak czytelnik oryginału, konfrontuje się $\mathrm{z}$ tak skonceptualizowanym obrazem świata, opartym na zaskoczeniu różnorodnością objawiającego się życia. Powstałe $\mathrm{w}$ oryginale wrażenie nadmiaru jest ujęte $\mathrm{w}$ konstrukcjach porządkujących metafory, co pozwala działać - jakby niezależnie - zdarzeniu, rzeczy oraz wyzwala metaforę, jak w obrazie Chrystusa jako lotnika. Tłumacz dostrzegł wartość tej poezji właśnie we wskazanej tu jukstapozycyjności składniowej jako podstawowym mechanizmie generującym jednoczesność przedstawienia wielu planów (dających możliwość wyrazu nowego czasu i nowej duchowości), zapoczątkowując kubizm poetycki $\mathrm{w}$ poezji polskiej $\mathrm{w}$ połączeniu $\mathrm{z}$ zapowiadanym przez

${ }^{20}$ Por. G. Apollinaire, Strefa, thum. A. Ważyk, „Almanach Nowej Sztuki” 1925 , z. 18 , s. $160-164$. 
Apollinaire'a nadrealizmem. Dlatego rzadko wprowadza amplifikacje, jak we fragmencie:

Et changé en oiseau ce siècle comme Jésus monte dans l'aire Les diables dans les abîmes lèvent la tête pour regarde ${ }^{2 I}$

'I zmieniony w ptaka wiek ten jak Jezus wstępuje w powietrze Diabły w przepaściach podnoszą głowę, żeby zobaczyć',

w którego przekładzie thumacz wprowadził metaforę amplifikacyjną, „ptak stulecia”, czyli aeroplan, wynikającą z ducha epoki zafascynowanej cywilizacją:

I zmieniony w ptaka niby Jezus wiek ten w powietrze uleci

$\mathrm{W}$ przepaściach diabły podnoszą głowę by spojrzeć w ptaka stulecia ${ }^{22}$.

Przewidywania czytelnika podążają na zewnątrz tekstu, ku jego doświadczeniom miejskim czasu rozwijającej się cywilizacji wraz z marzeniem ogarnięcia różnorodnej rzeczywistości.

Natomiast słoweński tłumacz opowiadania Sławomira Mrożka Wina i kara, niepotrzebnie dążąc do uzyskania spójności tekstu w płaszczyźnie prymarnej języka, zamyka drogę wycieczkom inferencyjnym, których sam chyba również nie odczytuje. Efekt groteskowy w opowiadaniu Mrożka powstaje na skutek przedstawionej niewspółmierności cech pozwalających szukać podobieństwa zachowań w zaburzeniach logicznego porządku wynikania, dzięki czemu odbiorca dostrzega zabawne, a zarazem groźne różnice między skontrastowanymi sensami i zdarzeniami. Niewspółmierność widoczna jest najczęściej wtedy, gdy porównuje się sens i język narracji. W oryginale krytyka wychowania totalitarnego oraz demaskacja tzw. ofiarności, będącej w zasadzie fanatyzmem, została przeprowadzona dzięki wielorakim możliwościom języka i mowy. Wśród nich na uwagę zasługują nacechowane ideologicznie wyrażenia oraz - w zakresie składni - wykorzystanie możliwości trybu przypuszczającego, fałszywej hipotezy i modalności. W dążeniu do spójności tłumacz popełnia też błędy znaczeniowe. Osłabia zaskoczenie wynikające $\mathrm{z}$ odkrycia absurdu, tym samym jego wyobraźnia semantyczna okazuje się niewystarczająca, by pobudzić wyobraźnię czytelnika i włączyć go w grę z tekstem. W oryginale grzech chłopca polega na tym, że:

${ }_{21}^{21}$ G. Apollinaire, Zone, w: idem, Alcools, Paris 1985, s. 9.
${ }_{22}$ G. Apollinaire, Strefa, s. 162. 
Wyjadał konfitury, garbił się, nie uważał i biegał²3.

W przekładzie:

[...] je jedel marmelado, se upiral, ne poslušal staršev in jima je ušel $^{24}$

'jadł konfitury, buntował się, nie słuchał rodziców i im uciekł’.

Niczym nieusprawiedliwiona zmiana znaczeń, a w konsekwencji sensu, przeprowadzona w celu rekonstrukcji spójności, nie tylko jest błędna, lecz niszczy wieloznaczność opowiadania, zachęcającą czytelnika do przewidywania dalszego ciągu, skonfrontowania własnego wnioskowania z tekstem, przeżywania zaskoczenia lub potwierdzenia swoich przypuszczeń. W tym pouczeniu dydaktycznym nie ma nic niespodziewanego. Podobne działanie mają komentarze interpretacyjne tłumacza.

Nieuzasadnione zmiany jednostkowych znaczeń oddalają przekład jeszcze bardziej od oryginału w przypadku, gdy ingerencje wykraczają poza słowo, dotyczą stylistyki. Mrożek łączy ze sobą różne poziomy stylistyczne: narrację bajki dziecięcej, pieszczotliwość (deminutywum), język propagandy lat 50. i 60., żargon podmiejsko-chuligański, dydaktykę świecką i religijną. $\mathrm{W}$ przekładzie granice między nimi ulegają znacznemu zatarciu. Fragment:

Nadeszła chwila, gdy małe serce służebnika w imię miłości dla Sprawy zabiło silniej niż wielkie serce Sprawy samej. Z miłości do Prawa przekroczyć Prawo. To miara ofiarności” ${ }^{25}$

w przekładzie został pozbawiony groteskowej wymowy, wynikającej z wieloznaczności odwołań filozoficzno-mistycznych, propagandowych oraz przesłania o niebezpiecznie płynnej granicy między obowiązkiem a jego nadużyciem. W rezultacie ironiczny sens tekstu - czynić Zło w imię Dobra - znika:

Prišel je trenutek, ko je majhno srce služabnika v ljubezni do Bistva začelo utripati hitreje kot veliko srce Bistva samega. V ljubezni do Pravičnosti je pozabil na Pravičnost samo. To je bila plemenitost ${ }^{26}$.

23 S. Mrożek, Wina i kara, w: idem, Opowiadania, Kraków 1974, s. 156.

24 S. Mrożek, Zločin in kazen, w: idem, Leteči slon, thum. B. Sömen, Ljubljana 1980, s. 68.

25 S. Mrożek, Wina i kara, s. 156-157.

${ }^{26}$ S. Mrożek, Zločin in kazen, s. 68. 
'Nadeszła chwila, gdy małe serce służebnika miłości do Istoty zabiło szybciej niż wielkie serce Istoty samej. Z miłości do Prawa zapomniał o samym Prawie. To była szlachetność'.

Ograniczenie wycieczek inferencyjnych czytelnika przekładu $\mathrm{w}$ omawianych utworach płynie $\mathrm{z}$ błędów tłumacza i częściowo z ubóstwa jego wyobraźni.

Tłumacz może zachować otwartość inferencyjną na różnych poziomach reekspresji, także na poziomie stylistycznym, wykorzystując kontekstowość znaczeń, czego dowodem jest przekład innego opowiadania Mrożka, Cierpienia młodego Werthera, którego autorem jest Niko Jež. Efekt groteskowy Mrożek uzyskał dzięki wykorzystaniu następstwa znaczeń wzajemnie się wykluczających oraz posługując się różnymi odmianami stylistycznymi języka, które charakteryzują uczestników dialogu. Dyrektor mówi językiem pełnym taktu, profesjonalizmu, zachowuje zasady wynikania logicznego, choć wie, że rozmówcy nie dorównują mu poziomem intelektualnym. Stylistyka jego wypowiedzi opiera się na modalności bliskiej semantyce, jaką niesie ze sobą - w języku francuskim - tryb subjonctif, w zakresie składni zaś typowe są dla wypowiedzi dyrektora zdania parentetyczne. Jego interlokutorzy wypowiadają się tymczasem prymitywnie, wtrącając znane slogany: „Przyszłość i tak należy do nas. Nie widzi pan, że jesteśmy młodzi” ${ }^{27}$; „Walka o sprawiedliwość ma pierwszeństwo” ${ }^{28}$. Podsumowując - stylistyka stron uczestniczących $\mathrm{w}$ dialogu pokazuje dzielącą je przepaść kulturalną i intelektualną.

Tłumacz nie jest w stanie oddać subtelności gry stylistycznej w dialogu nie tyle ze względu na ograniczenia systemowe języka przekładu, ile z powodu odmiennej praktyki językowej. Zachowując wierność oryginałowi, wprowadził zmianę w zakresie jednego ze zdań w wypowiedzi dyrektora:

To jest zupełnie możliwe, niemniej nie jestem pewien, czy się orientuję, $\mathrm{z}$ jakiego to powodu ${ }^{29}$.

W przekładzie zdanie to brzmi:

To bi bilo čisto mogoče, najbrž nisem dobro poučen o vaši zadevi ${ }^{\circ}$,

${ }_{27}$ S. Mrożek, Cierpienia młodego Werthera, w: idem, Dzieła zebrane, t. 2: Opowiadania i donosy 1980-1989, Warszawa 1995, s. 187.

${ }_{28}$ Ibidem, s. 188.

29 Ibidem, s. 187.

$3^{\circ}$ S. Mrożek, Trpljenje mladega Wertherja, tłum. N. Jež, „Ljubljanski dnevnik" 1989, nr 343, s. 14. 
choć teoretycznie można by powiedzieć:

'To bi bilo čisto mogoče, najbrž nisem prepričan, ali se orientiram iz kakšnega to razloga'.

Pomimo zbliżonej w obu językach gramatykalizacji zaskoczenia na poziomie składni (w języku polskim forma imitująca subjonctif, w języku słoweńskim - tryb przypuszczający), tłumacz zlikwidował wtrącenia oraz, na poziomie leksykalnym, użył słowa wyraźnie nacechowanego. Poučen oznacza pouczony przez kogoś, a więc niekoniecznie wyrażający własną wolę. Otwiera drogę przypuszczeń i przewidywań czytelnika dotyczących niewspółmierności słów: uczenie, uczenie się, pouczanie.

Dobrym przykładem zachowania kierunku wycieczek inferencyjnych obecnych $\mathrm{w}$ oryginale oraz dialogowego uruchomienia wyobraźni konkretnej i przedstawieniowej przez tłumacza jest przekład Trans-Atlantyku Witolda Gombrowicza na język słoweński.

Trans-Atlantyk już w płaszczyźnie narracyjnej i językowej zawiera obraz kultury polskiej, przywołany zwłaszcza dzięki odpowiedniemu ukształtowaniu wypowiedzi - przede wszystkim w sferze leksyki i składni oraz wzorców stylistycznych. Towarzyszą mu wzorce mentalne związane $\mathrm{z}$ dwoma kręgami kultury szlachecko-ziemiańskiej, wraz z ich mitami i obyczajowością: $z$ polowaniem, procesami i sporami o własność. $W$ języku oraz sposobie prowadzenia narracji jest zapisany wizerunek polskiej kultury zawierający stereotypowe wyobrażenia, wyrażone w mentalnym obrazie ojczyzny.

Niko Jež tłumacząc Trans-Atlantyk, zmuszony był nie tylko do zachowania wewnętrznej spójności sensu przekładu, ekwiwalentnej wobec oryginału, lecz także do ujawnienia jego dialogowości w perspektywie kultury polskiej i słoweńskiej. Niezmiernie ważny był wybór formy narracji. Narrator Gombrowicza jest opowiadaczem korzystającym z modelu gawędy szlacheckiej. Zanurzony w rzeczywistości własnej opowieści, bo do niej należy, ujawnia równocześnie swe punkty widzenia, opozycyjne w stosunku do form stylistycznych i ewokowanych przez nie treści, charakterystycznych dla gawędy. Często opowiadacz ograniczony jest swą wiedzą o świecie, dlatego nie potrafi dokonać konceptualizacji własnych spostrzeżeń w nowym (argentyńskim) otoczeniu. Składniowa, fonetyczna i fleksyjna konstrukcja jego wypowiedzi jest okaleczona, co wynika z ubogiego obrazu świata, który za nią się kryje. Ten narrator, narrator naiwny, współistnieje z narratorem krytycznym, posiadającym mentalne narzędzia koncep- 
tualizacji świata ${ }^{\mathrm{I}}$. Powstaje wrażenie, jakby cytował on cudzy i swój (sarmacki) punkt widzenia - to wynik przenikania się jego wypowiedzi: bełkotliwych, alogicznych, często w toku gawędowej narracji i zintelektualizowanej refleksji, w której mówiący nie moralizuje, lecz próbuje interpretować świat. Te dwie postawy narracyjne łączy poetyka narracji o charakterystycznym zrytmizowaniu wypowiedzi za pomocą rymów wewnętrznych w zdaniu i licznych współbrzmień. Struktura języka narratora stwarza wrażenie wzajemnego przedrzeźniania, powodując dystans do obu postaw światopoglądowych wyrażonych w narracji.

Tłumacz odnajduje właściwy ekwiwalent stylu Gombrowiczowskiego, podążając za tekstem oryginału. Wśród licznych trudności translatorskich, które napotyka, jedna mogłaby się wydawać barierą nie do przekroczenia. Mowa tu o narracji gawędowej - szczególnie sprawnym narzędziu w grze Gombrowicza, podejmującego polemikę na temat polskości w perspektywie wzorców przeszłości i sytuacji aktualnej. O ile dla odbiorcy oryginału $\mathrm{w}$ gawędzie zawiera się synteza polskości (również z perspektywy emigranta) ${ }^{32}$, o tyle dla thumacza znalezienie ekwiwalentu w kulturze słoweńskiej sprawiało pewne problemy. Stanął bowiem wobec podwójnej konieczności: wiernego oddania modelu świata obecnego w oryginale a wyrażonego już na poziomie języka oraz obowiązku respektowania świadomości kulturowej odbiorcy przekładu.

Gatunek gawędy obcy jest kulturze i literaturze słoweńskiej, lecz pewne formy narracyjne zbliżone do niej można odnaleźć w spominih, povestih, a także w kazaniach XVII-wiecznych, przede wszystkim Janeza Svetokriškiego (Tobiego Lionella), pomimo że służyły one osiągnięciu innego celu. Szczególnie przydatny jest wzorzec narracji obecny w tych ostatnich, trzeba by jednak odrzucić tu ich stronę moralizatorską zawartą w eksemplach. U Gombrowicza funkcjonuje bowiem sprzeczność, której nie można uniknąć na poziomie lektury: między tym, co moralne, a tym, co amoralne. Opozycja moralne - amoralne to jedna z ważniejszych opozycji w jego twórczości. Wybierając wzór stylizacji w postaci XVII-wiecznych kazań słoweńskich, tłumacz nie tylko odnalazł podobieństwo czasowego wzorca stylizacji wykorzystanego w oryginale, lecz mógł mieć też pewność, że odbiorca nie odrzuci przekładu jako tekstu zupełnie obcego swej świadomości

$3^{\text {I }}$ Na temat konstrukcji narratora w Trans-Atlantyku - por. S. Chwin, Sarmata kontestujacy, „Ruch Literacki” 1975, z. 4, s. 217-224.

${ }^{32}$ W rozmowie z Dominique de Roux Gombrowicz mówił: „Trans-Atlantyk zrodził mi się poniekąd jako Pan Tadeusz à rebours”. (D. de Roux, Rozmowy z Gombrowiczem, Paryż 1969, s. 93). 
i zrozumie sens gry prowadzonej przez Gombrowicza, jeżeli nie w zakresie skomplikowanej problematyki dotyczącej polskości, to $\mathrm{z}$ pewnością $\mathrm{w}$ zakresie niebezpieczeństwa zamknięcia w Formie. Tłumacz zastosował wzorzec kazań Svetokriškiego, co dało mu gwarancję odtworzenia opozycji (moralne - amoralne i moralne niemoralne) istotnych w oryginale. Tym samym zachowując sens tekstu wyjściowego, wpisał go w słoweński dyskurs literacki.

Wyobraźnia thumacza znajduje wyraz w semantyce i stylistyce, które są wynikiem jego zrozumienia i dewerbalizacji oryginału, a więc interpretacji i interioryzacji przedstawienia, dokonywanych przez niego jako uczestnika kultury docelowej i osobę przynależną w różnym stopniu do kultury wyjściowej. Reprezentuje on świadomość (i tym samym wyobraźnię jako rodzaj świadomości) wielowartościową ${ }^{33}$, skorelowaną często z przestrzenią zwielokrotnioną, czyli denotacyjnie i konotacyjnie skonceptualizowaną (mieszkaniec „ojczyzny wielokrotnej”)34. Wycieczki inferencyjne tłumacza - natrafiającego na różne trudności wynikające z odmiennych systemów językowych, stylów komunikacji kulturowej, tradycji, systemów światopoglądowych, systemów wartości itp. - zależą nie tylko od jego wyobraźni semantycznej, lecz od umiejętności wyboru z pola semantycznego własnego języka znaczenia ekwiwalentnego dla oznaczającej i symbolicznej funkcji leksemu lub wyrażenia w tekście wyjściowym. Jego wyobraźnia jest twórcza tylko wtedy, kiedy jest wielokrotna, czyli zdolna do kreatywnego działania językowego w co najmniej dwóch przestrzeniach. Wielokrotność ta jest niezbędna, by przekład był funkcjonalnie wierny, choć nie tożsamy $\mathrm{z}$ oryginałem, swojski i obcy równocześnie. Świat istnieje w sieci języka, o czym pisali filozofowie, Ernst Cassirer czy Susan Langer, a każdy język nieco inaczej go konceptualizuje, w wyniku czego różne są węzły dostępu do jego sensu:

Myśl o tym, że istnieją jakieś nie znane mi jeszcze fragmenty języka, napawa mnie lekkim przerażeniem, jakby tego rodzaju luki były zagubionymi fragmentami świata lub mego umysłu - jakby pełnia świata i umysłu była równoznaczna z pełnią języka. Albo, raczej, jakby język był ogromną misterną siecią, w której mieści się rzeczywistość; jeśli w takiej sieci znajdują się dziury, fragmenty rzeczywistości mogą się przez nie wymknąć, po prostu przestać istnieć35.

33 Por. E. Hoffman, Zagubione w przekładzie, thum. M. Roniker, Londyn 1995, s. 271.

34 Por. E. Balcerzan, Perehenia i stoneczniki, wstęp. S. Sterna-Wachowiak, Poznań 2003.

35 E. Hoffman, op.cit., s. 21. 
Tłumacz - znając węzły dwóch sieci, dzięki swojej wyobraźni, której wyrazem jest nowy kształt językowy tekstu - przyczynia się do wypełnienia przez odbiorcę docelowego luk konceptualizacyjnych, czyli do poszerzenia jego wiedzy, wrażliwości i postrzegania. Dysponuje więc świadomością dwu- lub wielowartościową. Edward Balcerzan przyznaje się do „ojczyzny wielokrotnej”, a Konstanty Jeleński - do świadomości wielokrotnej, pisząc o swoim nastawieniu do znanych mu języków. To interesujące, że znajomości języka nie łączył on z bliskim do niego stosunkiem, którym określał zadomowienie w języku, a więc tym samym w kulturze szeroko rozumianej, w aspekcie denotacyjnym i konotacyjnym. Pisał:

Z czterema językami łączy mnie bliski stosunek: polskim, włoskim, francuskim i angielskim. Po niemiecku mówię nieźle, ale pozostał to dla mnie ,język obcy” $[\ldots]]^{36}$.

W dokonywanych przez tłumacza wyborach wewnątrztekstowych, w wyborze strategii, jest miejsce na jego ograniczona samodzielność (autorstwo) i wyobraźnię, która jest jednym z czynników sprawczych w celu uzyskania inwariantu. Dzięki wyobraźni znajdują zastosowanie techniki przekładu, czyli środki transformacji translatorskiej, a wskutek napotykanych trudności w odnalezieniu właściwego ekwiwalentu sensu rozszerza się ich wachlarz. Przekład wymaga wyobraźni od thumacza, ponieważ: dokonywany jest $\mathrm{z}$ tekstu będącego całością zamkniętą, tzn. skończoną z punktu widzenia nadawcy, a jednocześnie całością niepełną, wymagającą konkretyzacji; jest przedstawieniem bez podmiotu przedstawiającego, $\mathrm{w}$ tekście thumaczenia bowiem można odnaleźć ślady tłumacza jako nadawcy sekundarnego oraz odbite w innym języku ślady autora i podmiotu literackiego; jest przedstawieniem bez rzeczywistości reprezentowanej, która istnieje w kontekście źródłowym.

Wyobraźnia jest zdolnością umysłu ukształtowaną na podstawie percepcji zmysłowej i umysłowej. Wynika $\mathrm{z}$ indywidualnych zasad przetworzenia danych postrzeżeniowych (bodźców zewnętrznych) oraz danych umysłowych (posiadanej wiedzy empirycznej i abstrakcyjnej) i potrzebuje zwykle bodźca, by uaktywniły się możliwości podmiotu wyobrażającego. Wyobraźnia obejmuje więc procesy asocjacyjne, w których obecny jest czynnik indywidualny i zbiorowy. Czynnik indywidualny zależy od psychicznych możliwości jednostkowych oraz od ukła-

${ }^{36}$ K.A. Jeleński, Szkice, wybór W. Karpiński, Kraków 1990, s. 7. 
dów wyobraźni, obecnych w kulturze, stworzonych na bazie konkretnych mechanizmów działających w strukturach artystycznych i paraartystycznych. Wyobraźnia czerpie zatem z postrzeganych rzeczy oraz przedstawień rzeczy i zjawisk, budując na ich podstawie światy alternatywne, artystyczne i paraartystyczne. Cechuje ją kreatywność, w różnym stopniu obecna w powstałych konstrukcjach. Można więc przyjąć, że stanowi ona medium analogowe oraz wykorzystuje tzw. wiedzę ukrytą. Sposoby transformacji wyobrażeń przez medium analogowe zależą nie tyle od wiedzy ukrytej, ile od własności jednostki dokonującej przeniesienia, natomiast wiedza ukryta zakłada sposób transformacji wyobrażeń podobny do utrwalonego $\mathrm{w}$ kulturze i rzeczywistości37. Jako funkcja umysłu opiera się na wspólnej ludziom zdolności mentalnej polegającej na budowaniu ciągów skojarzeniowych. Operacyjność tego mechanizmu mentalnego jest uzależniona od jednostkowego doświadczenia, wrażliwości i umiejętności oraz od doświadczenia zbiorowego, na przykład kulturowego.

Wyobraźnia w przekładzie ujawnia się najpierw ze strony thumacza, stanowiąc bodziec do aktualizacji semantyczno-stylistycznych oryginału. Później dopiero czytelnik przekładu włącza swą wyobraźnię interpretacyjną, na którą składają się zarówno wyobraźnia medium analogowego, jak i wiedza ukryta, czyli „wiedza uprzednia”, termin upowszechniony w przekładoznawstwie przez Romana Lewickiego ${ }^{3}$. Ze strony odbiorcy jest aktem świadomości. Poszukuje on Sartre'owskiego „analogonu przedstawienia", ponieważ czyta dzieło autora, nie zauważając najczęściej tłumacza. Wyobraźnia tłumacza oznacza jednocześnie wrażliwość na niuanse semantyczne tekstu oryginalnego - gdyż tłumacz ma dostęp do rzeczywistości przedstawionej w oryginale oraz zna rzeczywistość poddaną $\mathrm{w}$ oryginale reprezentacji.

Wydaje się, że wyobraźnia w przekładzie związana jest z postawą świadomości, dla której bodziec stanowią struktura i materia tekstu. Natomiast mechanizm wyobrażenia ma charakter wrodzony. Prawdopodobnie dlatego Erich Fromm uznawał wyobraźnię za zdolność wrodzoną, nie wyjaśniając szerzej przesłanek takiego twierdzenia. Wrodzony jest mechanizm mentalny pozwalający generować wyobrażenia na podstawie doświadczenia zmysłowego i umysłowego, czyli wiedzy nabytej, obowiązującego systemu wartości, światopoglądu, osobowości postrzega-

37 Por. Z.W. Pylyshyn, Spór o wyobraźnię: medium analogowe czy wiedza ukryta, thum. J. Suchecki, w: Psychologia poznawcza w trzech ostatnich dekadach XX wieku, red. Z. Chlewiński, Gdańsk 2007, s. 366-408.

${ }^{8}$ Por. R. Lewicki, Obcość w odbiorze przekładu, Lublin 2000, s. 97-109. 
jącego itp., o czym przekonuje psychologia kognitywna ${ }^{39}$. Sens i wartości, jakie niesie struktura artystyczna tekstu literackiego, wykraczają poza jednostkowy tekst, który jest postrzegany i wyobrażany przez czytelnika. Tłumacz jako czytelnik postrzega go i wyobraża w procesie interpretacji będącej formą interioryzacji, ponieważ dzięki temu możliwy staje się transfer do innej kultury. Przeniesiony tekst wchodzi w niej w interakcje wyznaczone przez odmienne parametry właściwe dla kultury przyjmującej. Transferu dokonuje thumacz, którego kompetencje i wyobraźnia decydują o jakości przekładu i jego zadomowieniu w kulturze przyjmującej.

Akt wyobraźni [...] jest - jak pisze Jean-Paul Sartre - aktem magicznym. Jest zaklęciem przeznaczonym do wywołania przedmiotu, o którym się myśli, rzeczy, którą się pożąda w taki sposób, aby można ją było wziąć w posiadanie. Jest $\mathrm{w}$ tym akcie zawsze coś rozkazującego i coś dziecinnego, odmowa brania pod uwagę odległości i trudności ${ }^{4}{ }^{\circ}$.

Jest więc aktem intencjonalnym, określonym przez filozofa jako pewna świadomość, zjawisko pozornej obserwacji, spontaniczne, zakładające nieistnienie swego przedmiotu. Wyobrażenie jest jednym z typów świadomości. Różni się na przykład - jak pisze Sartre - od postrzegania i myślenia (pojmowania), gdyż te odnoszą się do tego samego przedmiotu. Postrzegając, dokonuje się obserwacji przedmiotu $\mathrm{z}$ jakiegoś punku widzenia, nigdy ze wszystkich stron równocześnie. Myślenie o przedmiocie obejmuje wielość jego przejawów, wiedzę o nim. W wyobrażeniu wiedza o przedmiocie pojawia się natychmiast, ponieważ łączy się w nim wiedzę konkretną, nieobrazową z „elementami przedstawiającymi”. Wiedza i przedstawienie są ze sobą połączone. Wywoływany przez wiedzę przedmiot nie istnieje, pojawia się w świadomości pod wpływem jakiegoś bodźca postrzeżeniowego, zmysłowego lub umysłowego ${ }^{41}$. Takim bodźcem może być słowo, zdarzenie, postawa postaci, wyznanie itp. Wydaje się, że to dlatego dla Gastona Bachelarda, podobnie jak dla wielu poetów, wyobraźnia poetycka oznacza wrażliwość na niuanse semantyczne słowa ${ }^{42}$.

Tłumacz korzysta z wyobraźni, zmierzając do oddania tego samego doznania, przeżycia artystycznego, emocjonalnego, sys-

39 Por. m.in. S.P. Kosslyn, J.R. Pomerantz, Imagery, propositions and the form of internal representations, „Cognitive Psychology” 1977, nr 9, s. 52-76.

$4^{\circ}$ J.P. Sartre, Wyobrazienie, thum. P. Beylin, Warszawa 1970, s. 225.

${ }^{4}$ Zob. ibidem, s. 14-38.

$4^{2}$ Por. G. Bachelard, op.cit. 
temu wartości i emocji z nimi związanych oraz sensu w przypadku braku bezpośrednich ekwiwalentów leksykalnych, morfologiczno-składniowych i stylistycznych lub innego ich nacechowania semantyczno-emocjonalnego itp. Ma bowiem obowiązek dostarczyć czytelnikowi przekładu takich samych przeżyć, jakich doznaje czytelnik oryginału, jakich doznał on sam, czytając oryginał. Jego kreatywność polega na znalezieniu takiego dostępu do sensu, który zapewniłby odbiorcy cały wachlarz możliwości konkretyzacyjnych (emocjonalnych, intelektualnych, estetycznych, metafizycznych i innych) obecnych w oryginale. Tak, by słowa nie tylko to samo znaczyły, lecz by również tak samo aktywizowały wyobraźnię czytelnika przekładu. Słowo jest zakorzenione w kontekście konkretnej kultury, posiada swoje znaczenie słownikowe i kontekstowe, a także indywidualne, osobnicze używającego go podmiotu. Stanowi uznakowioną formę tożsamości jednostkowej i zbiorowej. Wywołuje nieistniejący przedmiot $\mathrm{w}$ świecie wyobraźni i przeżyć $\mathrm{z}$ nią związanych, czemu poświęciła swój „pamiętnik semantyczny” ${ }^{33}$ Eva Hoffman, pisząc o zdobywaniu wielowartościowej świadomości na drodze triangulacji psychologicznej, gwarantującej zachowanie tożsamości podmiotu:

Po polsku słowa „chłopak” i ,dziewczyna” miały w sobie wiatr i zamaszystość chłopięcości, powiew i urok dziewczęcości, ewokowały ów przelotny ruch, melodię $\mathrm{i}$ aromat, które są wewnętrznymi odbiciami danej płci. Po angielsku słowa „mężczyzna” i „kobieta” były pustymi znakami; czułe słowa wydawały się równie formalne i prymitywne jak inne wyrazy. W tej neutralnej i wykastrowanej mowie słowa nie miały ani rodzaju męskiego, ani żeńskiego, nie wyrastały z substancji erotycznej, z seksu ${ }^{44}$.

Eva Hoffman wybiera słowa o podwójnym nacechowaniu emocjonalnym - neutralnym (odnoszącym się do gatunku ludzkiego) oraz silnym (pozytywnym i negatywnym w zależności od użycia kontekstowego) - chcąc podkreślić ich rolę w uzewnętrznianiu tożsamości podmiotu w sferze doznań intymnych. Podkreśla tym samym identyfikacyjną funkcję mowy ${ }^{45}$. Autorka koncentruje się na metaforycznie rozumianym przekładzie, czyli

43 Określenie Stanisława Barańczaka (zob. S. Barańczak, Pomieszanie języków, w: idem: Tablica z Macondo, Londyn 1990, s. 203-204).

44 E. Hoffman, op.cit., s. 243.

45 Eva Hoffman pisze o tym już w języku angielskim. Cytat jest przekładem, więc należałoby sprawdzić, jak poradziła sobie jej wyobraźnia w odnalezieniu właściwej ekspresji w języku angielskim. 
na przełożeniu własnej osobowości na język, by w nim potwierdzić samorozumienie i rozumienie świata.

Człowiek, który wypowiada obce sformułowania nie usiłując przyswoić sobie ich znaczenia, ryzykuje wulgaryzację własnej osobowości. Prawdziwe thumaczenie musi opierać się na zrozumieniu i sympatii; odbywa się ono stopniowo i powoli, zdanie po zdaniu, fraza po frazie ${ }^{46}$.

Eva Hoffman zakłada tym samym kontekstowy charakter znaczeń, czyli że nawet w przypadku istnienia ekwiwalentów słownikowych są między nimi różnice, wynikające z kontekstowego ich użycia. Wyobraźnia użytkownika języka wydobywa obrazy i znaczenia spontanicznie $\mathrm{z}$ całościowego pola semantycznego leksemu, z jego encyklopedii semantycznej - jak to ujmuje Eco - aktualizując je w określonym celu i sytuacji. W wyobraźni bowiem unaocznia się natychmiast cała wiedza, która łączy konkretną wiedzę językową związaną z możliwymi desygnatami słów „chłopak”, „dziewczyna” oraz elementy przedstawiające $\mathrm{w}$ literaturze, sztuce, piosence, $\mathrm{w}$ obyczaju, folklorze, żarcie itp. $\mathrm{Z}$ indywidualnego przetworzenia (interioryzacji) elementów przedstawiających pochodzą skojarzenia $\mathrm{z}$ „zamaszystością chłopięcości” i „urokiem dziewczęcości”. Asocjacje te nie mają jednego konkretnego źródła, będąc amalgamatem znanych i przeżytych obrazów $z$ wiedzą ukrytą. Inne jest umocowanie indywidualne i zinterioryzowanie zbiorowe ekwiwalentów tych leksemów w drugiej kulturze, do którego inny jest (ze względu na owe konteksty) dostęp semantyczny.

\section{BOŻENA TOKARZ}

\section{Translator's inferential excursions, with imagination in the background}

In a literary work, signals that trigger reader's inferential excursions allow the reader's imagination to identify with and control the represented world. They constitute an important element of sense-generating mechanism. Thanks to imagination, the translator imitates the inferential mechanism of the original on various level's of the text's structure, activating the imagination of the reader. The translator's imagination is bi- or multivalent in having the linguistic-semiotic, literary, and cultural quality. Although it manifests itself in language, it goes beyond the boundaries of language.

${ }^{46}$ E. Hoffman, op.cit., s. 209. 
Imagination is a form of consciousness which has no object of its own, and a medium connecting a specific non-imaginary knowledge with representations. It constitutes a mind faculty shaped on the basis of sensory and mental perception. It is derived from individual principles of perception and cognition data processing. It usually requires a stymulus to activate the capabilities of the imagining subject. As a mind faculty, imagination is based on the mental capability common to all people, which is the ability to create chains of associations.

Translator's respect for inferential excursions in the original text is necessary for retaining the original meaning, regardless of whether they occur on the phonetic-phonological level (as in Ionesco's The Chairs), or on the level of image-semantic and syntactic relations (as in translation of Apollinaire's Zone), or on the level of syntax (as in translation of Mrożek's short stories into Slovenian), or on the level of cultural communication (as in Slovenian translation of Gombrowicz's Trans-Atlantic).

Keywords: translation, imagination, sense, inferential excursions.

Bożena Tokarz - profesor zwyczajny w Instytucie Filologii Słowiańskiej UŚ, kierownik Zakładu Teorii Literatury i Translacji; badaczka XX-wiecznej literatury polskiej i słoweńskiej; zajmuje się teorią literatury, komparatystyką, teorią przekładu, poetyką historyczną. Autorka między innymi książek: Teoria literatury. Metodologia badań literackich (1980, ze Stefanem Zabierowskim), Mit literacki. Od mitu rzeczywistości do zmiany substancji poetyckiej (1983), Poetyka Nowej Fali (1990), Wzorzec, podobieństwo, przypominanie. (Ze studiów nad przektadem artystycznym) (1998), Między destrukcja a konstrukcja. O poezji Srečka Kosovela w kontekście konstruktywistycznym (2004), Spotkania. Czasoprzestrzeń przekładu artystycznego (2010); redaktor serii przekładoznawczej „Przekłady Literatur Słowiańskich” (t. 1-4).

e-mail: tokarzbozena@gmail.com 